\title{
A Nulidade Parcial
}

Daisy Gogliano

Mestre (Docente Voluntário) em Direito Civil da Faculdade de Direito da USP

RESUMO: Noçōes Introdutórias: 1. Os atos nulos e anuláveis; 1.1. O ato anulável - a) no direito francês. b) no direito alemāo. c) no direito italiano. 1.3. Síntese conclusiva; 1.4. Exceções nas características dos negócios nulos. 2. conceito de nulidade parcial. 2.1. A nulidade parcial nas diversas espécies de negócios. 2.1.1. Negócios típicos e atípicos; 2.1.2. Negócios simples e complexos; 2.1.3. Negócios jurídicos unilaterais: inter vivos e mortis cansa; 2.1.4. Negócios patrimoniais e não patrimoniais; 2.1.5. Negócios familiares. 3 . O princípio da conservação. 4. A nulidade parcial em nosso ordenamento. 5. A nulidade parcial - características. 6. Conclusōes.

\section{NOÇŌES INTRODUTÓRIAS:}

\section{Os atos nulos e anuláveis:}

Para que possamos falar da nulidade parcial na teoria geral dos negócios, necessário se faz tecer algumas consideraçōes preliminares a respeito dos atos nulos e anuláveis, que se inserem no plano da validade, à luz do magistério de Antonio Junqueira de Azevedo, em sua lapidar monografia - Negócio Jurídico - existência, validade e eficácia - ${ }^{(1)}$, demonstrando que a clássica distinção entre nulo e anulável não pode ser encarada sob um prisma rígido e imutável, como pode parecer, uma vez que, em seu mecanismo técnico e sensível as variações de ordem histórica e social.

\subsection{O ato nulo:}

Na linguagem de PONTES DE MIRANDA, "O nulo é ato que entrou, embora nulamente, no mundo jurídico".

$\mathrm{O}$ ato jurídico nulo não se confunde com o ato existente, pois "o ato jurídico nulo entrou no mundo jurídico: se assim não fosse, nulo seria igual a existente? não haveria distinção entre ser e o ser nulamente. Já no suporte fático está $o$ déficit, o ato penetrou no mundo jurídico, embora nulamente,

(1) Antonio Junqueira de Azevedo. Negócio Jurídico. p. 63. 
exposto, de regra, como ato jurídico de suporte fático gravemente deficitário, a ataques fáceis e de quem quer que tenha interesse. Não nasceu morto, o que seria não nascer; não nasceu impróprio à vida, por sua extrema debilidade", conforme PONTES DE MIRANDA ${ }^{(2)}$.

Temos como princípio comum no direito, que o ato nulo é aquele que não produz efeitos e que não pode nunca ser convalidável ou sanável.

\section{2. $\mathrm{O}$ ato anulável:}

É aquele que produz efeitos provisóriamente, e, portanto, pode ser sanável e convalidável.

Conforme EMILIO BETTI: “A anulabilidade corresponde, de acordo com tudo que dissemos, à deficiências do negócio consideradas menos graves do que aquelas que produzem a sua nulidade, segundo uma avaliação contingente, feita pela lei, dos interesses a tutelar. De um modo geral, pode dizer-se que há anulabilidade quando falte um pressuposto de validade, ou quando um elemento essencial do negócio esteja simplesmente viciado; ao passo que só existe nulidade, quando falta um elemento constitutivo do negócio, ou este se apresenta deficiente na configuração exigida pela lei"'(3).

$\mathrm{Na}$ teoria das nulidades, as posições variam segundo a doutrina de cada país. Assim, para que possamos ter uma visão mais aprofundada dos sistemas das nulidades, necessário se faz remeter às posiçōes mantidas por várias legislações. É o que nos propomos, com fundamento no trabalho desenvolvido por GUGGENHEIN ${ }^{(4)}$.

\section{a) no direito francês:}

De acordo com as várias posições tomadas pelos autores franceses, temos que:

Segundo DEMOLOMBE e COLMET DE SANTERRE, sectários da teoria dos atos existentes, "o ato é nulo quando a lei o priva dos efeitos sem que haja necessidade de o fazer anular por julgamento".

Para AUBRY e RAU, "a ineficácia de um ato, independe de qualquer declaraçāo judiciária; pertence a todo juiz reconhecê-la, mesmo de ofício. Não é

(2) PONTES DE MIRANDA. Tratado de Direito Privado. V. IV - p. 28.

(3) EMILIO BETTI. Teoria Geral do Negócio Jurídico, t. III, p. 21.

(4) DANIEL GUGGENHEIM. L'Invalidaté des actes juridiques, p. 12. 
possível caso de nulidade, porque não é possível anular o que não existe" (no caso do ato inexistente).

Quanto ao ato nulo, a nulidade jamais pode ser de pleno direito em virtude da lei; mesmo nos casos em que a lei qualifica de nulidade de pleno direito, ela deve ser pronunciada pelo juiz.

Em conclusão as posiçōes podem ser assim assumidas:

a) $\mathrm{O}$ ato não pode ser assim declarado de pleno direito. A nulidade deve ser invocada pela parte, por via de ação ou por via de execução, devendo, por conseguinte, ser pronuciada pelo juiz, pois é a declaração de nulidade que dará à existência do ato;

b) Em princípio a nulidade não pode ser invocada, a não ser pelas pessoas em favor das quais foi estatuída. Para isto, os autores buscam o interesse privado ou público. Quando ocorre o interesse privado, a nulidade é relativa; se público, a nulidade é absoluta. A nulidade absoluta é aberta a qualquer um, no sentido de demonstrar um interesse para que se pronuncie a nulidade do ato a nulidade relativa, cabe somente à pessoa que pode demonstrar que ela foi estatuída em seu favor. Sob o ponto de vista passivo, a nulidade pode ser invocada contra qualquer pessoa;

c) É possível a validade de um ato, em princípio válido, afetado de um vício originário. $O$ ato pode șer confirmado, através de prescrição da ação, que é considerada como uma confirmação tácita.

\section{b) no direito alemāo:}

No direito alemão, o ato pode ser nulo ou anulável. $\mathrm{O}$ ato nulo, é aquele que não produz todo o efeito jurídico designado como querido. Como se observa, a doutrina alemã se refere aos efeitos como queridos, sem levar em conta outros efeitos que o ato pudesse produzir. Por outro lado, a nulidade opera de pleno direito, sem a necessidade de uma declaração judicial provocada por intermédio das partes, e o juiz deverá reconhecê-la de ofício, toda vez que a conhecer.

Ainda, o ato nulo, não será válido, nem pela confirmação, como pela prescrição ou pelo desaparecimento da causa da nulidade.

Quanto ao ato anulável, este se aproxima do ato válido, por ser um ato que produz todos os seus efeitos. Diferentemente do direito francês, o ato poderá ser declarado anulável, em razão da simples declaração da parte. Toda pessoa que tenha conhecimento do vício, poderá invocar a anulação do ato. 
Assim, se durante um espaço de tempo não for declarado anulável, haverá a confirmação, que corresponde ao direito de renúncia ao direito de anulação.

\section{c) no direito italiano:}

O direito italiano, no mesmo passo do direito alemão distingue os atos em nulos e anuláveis. $\mathrm{O}$ ato nulo, será nulo de pleno direito e sua nulidade poderá ser invocada e o juiz poderá declará-la de ofício. Como ato nulo, este não poderá ser convalidado. Exclue-se em princípio a confirmação e a prescrição da ação.

Já o ato anulável, como no direito alemão é aquele que em princípio produz todos seus efeitos; sendo provisoriamente válido, só determinadas pessoas, de acordo com as determinações da lei, poderão invocar a nulação do ato.

Contrariamente ao direito alemão, não existe uma declaração unilateral de vontade, no sentido de tomá-lo e mefeito no julgamento de tal estado.

O critério distintivo entre o ato nulo e o anulável, está em que, o ato é nulo quando falta um elemento essencial; e anulável quando os seus elementos se encontram viciados.

Mas, este princípio nao é totalmente seguido, pois, como informa CARIOTA FERRARA, muitas vezes, um ato na falta de um e seus elementos essenciais, não é considerado eivado de nulidade, como acontece no erro essencial e na incapacidade natural, dando lugar a uma simples anulação. Por outro lado, um simples vício de um elemento, pode não acarretar a anulação.

\subsection{Síntese Conclusiva:}

Para BETTI distinção entre nulidade e anulabilidade, indicam, ao mesmo tempo, uma pradação da invalidade e um critério para delimitar as respectivas esferas de aplicação ${ }^{(5)}$.

Para o jurista italiano, é NULO o negócio que, por falta de algum elemento essencial, corresponde à configuração exigida, seja inidôneo para dar vida àquela nova situação jurídica que o direito liga ao respectivo tipo legal, em conformidade com a função econômico-social que o caracteriza: é nulo, embora possa, eventualmente, produzir alguns efeitos que lhes correspondem ou outros diferentes, de caráter negativo ou aberrante (pois que, de outro modo, seria antes de qualificar como inexistente) ${ }^{(6)}$.

(5) BETTI - op. cit. tomo III - pg. 21.

(6) BETTI - op. cit. tomo I1I - pg. 22. 
Portanto, a distinção entre nulo e anulável deve, outros sim, ser encarada sob o prisma do mecanismo técnico posto pela lei, e este não é imutável, mas sensível às variações das condições históricas.

Para BETTI, o ponto decisivo da diferenciação entre nulo e anulável e que, "nos casos em que a ordem jurídica, em concordância com a consciência social, é levada a considerar o ato de autonomia privada como afetado por uma deficiência intrínseca, é sempre crer que o problema do tratamento seja resolvido no sentido da nulidade"'( $)$.

Um exemplo: É o que se dá ao critério da repartição entre nulidade e anulidade no caso do testamento: orientam o tratamento no sentido da nulidade aquelas inobservâncias que comprometem a função ratificadora do documento e ponham em perigo a proveniência da declaração do testador; orientam no sentido da anulabilidade as inobservâncias que, em excluir a certeza da proveniência fazem surgir dúvidas sobre a certeza, ex., da atendibilidade do documento. ${ }^{(8)}$

PONTES DE MIRANDA diz que os atos jurídicos strictosensu nulos ou os negócios jurídicos nulos são os que foram criados com vício grave tal, que:

a) são insanáveis as suas invalidades e irratificáveis, tanto que, a rigor, não há confirmação de atos ou negócios nulos; há firmação nova, ex nume, de forma alguma confirmação;

b) qualquer interessado, e não só o figurante pode alegar e fazer ser pronunciada a nulidade, dita, então deficiência absoluta;

c) o juiz pode decretá-la de ofício;

d) não necessita de ação própria e até "incidenter" é suscetível;

e) nao corre prescrição da pretensão à nulidade;

f) é sem efeito.

No que se refere à anulabilidade, entende Betti por ANULÁVEL, o negócio em que ainda não lhe faltam os elementos essenciais do tipo, e embora dando vida precária à nova situação jurídica que o direito refere ao tipo legal possa, após reação da parte interessada, ser removido como preceito, com efeitos retroativos, e considerado como se nunca tivesse existido. A anulabilidade corresponde a deficiências do negócio consideradas menos graves do que aquelas que produzem a sua nulidade, segundo uma avaliação contingente feita pela lei, dos interesses a considerar. ${ }^{(9)}$

(7) BETTI - iden - ibidem - p. 26.

(8) BETTI - idem - ibidem - pg. 27.

(9) BETTI - op. cit. - pág. 22. 
Assim, pode dizer-se que "há anulabilidade quando falta um pressuposto de validade, ou quando um elemento essencial do negócio esteja simplesmente viciado, como são os casos de: falta de capacidade ou de legitimação; já, a nulidade exite quando falta um elemento constitutivo do negócio, ou este se apresenta deficiente na configuração exigida pela lei; assim deriva nulidade, a falta da forma prescrita pela lei; a falta de acordo no contrato; a ausência ou ilicitude da causa; a inidoneidade do objeto.

Lembramos que é importante frisar que a nulidade e a anultibilidade, se referem às qualidades dos elementos, segundo a lição de JUNQUEIRA DE AZEVEDO; Não há falta de elemento; o que há é simplesmente a falta ou deficiência das qualidades dos elementos do ato, no plano da validade.

Quanto à anulabilidade, esta pode ser requerida pela parte legitimada no negócio e que tem interesse. Quando anulável, o negócio, produz efeitos, mesmo precários, até que a iniciativa destinada a anulá-lo tenha obtido êxito.

A anulabilidade, segundo BETTI, é a figura da invalidade que mais se aproxima da ineficácia superveniente, após reação dos interessados. ${ }^{(10)}$

O negócio anulável é sempre suscetível de revalidação, que não faz nascer novo regulamento de interesses, mas, apenas confirma e reforça aqueles mesmos interesses.

A anulabilidade, por sua vez, é prescritível.

PONTES DE MIRANDA assinala que o conceito de anulabilidade se compôs do direito comum, não sem grandes confusōes com o de ineficácia; nulo, segundo ele, é ato que entrou, embora nulamente, no mundo jurídico. Também, entrou, e menos débel no mundo jurídico, o suporte fático do negócio anulável. A distinção é intensa, no plano da validade, baseada em maior ou menor gravidade do defeito. E acrescenta PONTES: "Nada adianta aduzir-se que a anulabilidade é mais próxima da ineficácia superveniente; nem é suportável ao espírito científico o distinguirem-se existente e nulo, e falar-se de declaração de um e de outro, pois a decisão declarativa supõe existência ou inexistência, e nunca pode subir ao plano da validade. Nesse, a distinção entre nulidade e anulabilidade é criação técnica, que determina tratamentos diferentes, um dos quais é o da imprescritibilidade das açôes de nulidade, ligada a sua irrenunciabilidade".

"Seja como for, é técnica legislativa que toca discriminar as causas de nulidade e as de anulabilidade para que se observem os dois regimes, internos

( I0) BETTTI - op. cit., - pág. 24. 
ao plano de validade, atendidas modificações que se entendam, na lei, indispensáveis. Quase sempre, essas modificações de limites entre as duas espécies de invalidade provêm de causas históricas, de pedaços de sistemas jurídicos diferentes (e. g., o romano, o germânico, o canônico, o faroleiro), que perduram no sistema jurídico vigente"(11).

Conforme a opinião de ANTONIO JUNQUEIRA DE AZEVEDO, na teoria clássica, o ato anulável é como a criança que nasce fraca, com problema orgânico, que se destina a alguns momentos de vida, mas que provavelmente morrerá. $\mathrm{O}$ ato anulável, ao contrário do nulo, que já nasce morto, vem a falecer depois, com a decretação da anulabilidade.

Assim, diz-se do ato anulável:

a) que produz efeitos até ser anulado;

b) que é prescritível;

c) que é ratificável, convalidável;

d) precisa de açāo específica para ser anulado;

e) o seu defeito é interesse particular.

Apresentadas as características mais comuns dos atos nulos e anuláveis, com base na doutrina clássica, cuja "summa divisio", como veremos é das nulidades absolutas e relativas, passaremos às questões de maior importância, relativas aos chamados EFEITOS DO NULO.

Após Q aparecimento da teoria da INEXISTÊNCIA, o bem delineado quadro da teoria clássica ficou abalado, dando-lhe JAPIOT o golpe mortal, em seu tratado sobre as nulidades, onde demonstra que a nulidade dividida entre atos nulos e anuláveis não é da natureza ou estado do ato, mas, como vimos, é sançāo, què o legislador atribui, devendo examinar-se cada artigo de lei que trata de nulidades, para saber qual o sentido, qual a interpretação a ser dada. Não se deve atribuir uma qualidade ao ato, mas deve-se perquirir qual a conseqüência que o legislador prevê para certas faltas.

Temos, pois, um verdadeiro direito de crítica aos negócios jurídicos: se o legislador deu direito de crítica a todas as pessoas, temos a nulidade absoluta; caso contrário, encontramo-nos diante das nulidades relativas.

(11) PONTES DE MIRANDA - Tratado - vol. IV - pág. 30. 


\subsection{EXCEÇŌES NAS CARACTERÍSTICAS DOS NEGÓCIOS NULOS:}

A) insanibilidade do nulo: o art. 208 do Código Civil é exceção à regra de que $o$ ato é insanável. Referindo-se à nulidade a qual pode ser sanada com o tempo, mostra a possibilidade de o nulo produzir efeitos.

PONTES DE MIRANDA, afirma que o art. 208 é uma aberração dentro do sistema do nosso código, é reminiscência histórica do desprezo do velho direito canônico às formas ${ }^{(12)}$.

Relativamente aos artigos 211 e 215 entende serem casos de anulabilidade e não de nulidade, comentando PONTES, que a ratificabilidade existiria (art. 148), ainda se nāo houvesse incluído o art.211. Dá-se o mesmo quanto ao art. 215. E acrescenta: "O conteúdo de negócio jurídico nulo é ligado ao de insanabilidade; a sanatória do nulo é contradictio in terminis; dissemos. A espécie do art. 208 grita, no sistema jurídico; como outros resíduos de séculos mortos, porém náo de todo extintos por alguns espíritos, ocasionalmente encarregados de redigir leis. A exigibilidade da ação ordinária (art. 222) para a decretação da nulidade do casamento, não; não; não nos causa ela tal perplexidade; porque, para a aplicação do direito objetivo, o Estado é livre (para exigir esse ou aquele rito ou forma, sem cair, em contradictio in terminis; o conceito de nulidade nada tem de necessáriamente ligado à decretabilidade de ofício; e pode haver, e há espécies, em que a cognição do magistrado, em processo regular, é necessária, ou, pelo menos, útil. É de lamentar-se que, a respeito, muitos juristas ainda estejam saturados do romanismo, ou em estado de confusão, devido aos dois conceitos, o romano de nullus e o moderno de "nulo"(13).

b) o ato nulo é imprescindível: Atualmente, por força das decisões jurisprudenciais, admite-se a prescritibilidade do ato nulo em matéria patrimonial. E $\mathrm{cm}$ alguns casos a prescritibilidade em ações pessoais;

c) o ato nulo nāo produz efeitos: Casos há, como tivemos oportunidade de ver, em que o nulo produz efeitos. São os exemplos: o casamento putativo; o casamento no caso em que a mulher não deixou transcorrer o prazo de 300 dias; no direito do trabalho os contratos de trabalhos nulos que produzem efeitos enquanto cumpridos pelas partes; em matéria de sociedade limitada, contrato social, que mesmo nulo, vigora em relação a terceiros que tenham contrato com a sociedade;

Em várias legislaçōes, quando o negócio jurídico é nulo em virutude do erro, ou quando a parte que realizou o ato agiu sem seriedade, deve pagar o interesse negativo. Como acontece na doutrina alemã e suíça.

(I2) PONTES DE MIRANII)A - Tratado - vol. IV - pág. 47.

(13) PONTTES DE MIRANDA - Tratado vol. IV - pág. 47/48. 
d) o ato nulo não necessita de açāo específica para que seja declarada a nulidade: Segundo o art. 222 do C. Civil, a nulidade do casamento processarse-á por ação ordinária, com a nomeação do curador; ainda, para intentar a ação, o autor tem que estar legitimamente constituido; o que destrói a afirmação de que a nulidade pode ser arguida por qualquer pessoa.

Salientamos a opinião de PONTES DE MIRANDA, que entende não existir qualquer perplexidade quanto ao art. 222, pois para a aplicação do direito objetivo, o Estado é livre para exigir qualquer forma ou rito, sem que haja contradição. E o conceito de nulidade, nada tem de haver com a decretabilidade de ofício.

e) os atos nulos dizem respeito à ordem pública; $O$ que nem sempre acontece, pois, o conceito de ordem pública, ainda não está claramente definido, e, em nosso sistema, os casos de incapacidade, ora são colocados como nulos, ora como anuláveis, o que estaria a indicar que os casos em que existe a menoridade abaixo de 15 anos, seria ordem pública; enquanto a capacidade relativa, interessaria à ordem particular.

Por exemplo, no caso da simulação, a qual é considerada no campo da anulabilidade. Com o Projeto/75, a simulação passou a ser considerada entre os atos nulos, interessando, daí, à ordem pública. Portanto é vago o conceito de ordem pública, como critério distintivo entre nulo e anulável.

Pois bem. Todos esses pontos, acima colocados, fazem com que se possa afirmar que a clássica dicotomia entre as nulidades absolutas e relativas, não pode ser aceita de maneira rígida e inflexível.

Passaremos, agora, a estudar o cerne da questão relativa ao presente estudo - a nulidade parcial -, levando em conta todas as colocações anteriormente delineadas, as quais têm íntima relação com o nosso tema a seguir.

\section{Conceito de nulidade parcial.}

Na definição de CRISCUOLI considera-se nulidade "a máxima sanção civil com a qual e ordenamente jurídica afeta uma parte de uma 'fattispecie' negocial que resulta contraria aos limites impostos à autonomia privada, negandolhe reconhecimento e tutela jurídica"(14).

CRISCUOLI considera a nulidade, tanto a total, como a parcial, como sanções dogmaticamente consideradas. A nulidade de parcial ocorre quando os preceitos ditados e emanados pelas partes apareça ilícito, imoral ou ilegail, con-

(14) GIOVANNI CRISCUOLI. La Nullità Parziale del Negozio Giurídico, p. 1,30. 
trário ao ordenamento, surgindo uma contradição entre os preceitos editados pelas partes com a norma de direito objetivo e a parte da fattispécie então criada.

Como tivemos oportunidade de ver em Emili BE,S).eT.

Como tivemos oportunidade de ver em EMILIO BETTI, o negócio jurídico "é ato pelo qual o indivíduo regula, por si, os seus interesses, nas relaçōes com outros (ato de autonomia privada): ato ao qual o direito liga os efeitos mais conformes à função econômico-social que lhe caracteriza o tipo."

Mas, a autonomia privada, segundo BETTI, "quando é chamada a atuar no plano social, encontra, antes de mais nada, limites e obedece a exigências que provém da sua própria lógica: limites e exigências, que antecedem, neste sentido, o próprio reconhecimento jurídico. Em virtude desse reconhecimento, ela encontra, depois, outros limites e obedece a ulteriors exigências dela derivadas, na medida em que é chamada a atuar no plano de direito e segundo a lógica deste. $\mathrm{O}$ reconhecimento jurídico confirma, aceita e, quando necessário, modifica limites e exigências naturais da autonomia privada" (15).

Quando o negócio jurídico atende todos os limites e todas as exigências impostas pela ordem jurídica, como "recompensa" passa a ser reconhecida, valendo como preceito normativo entre as partes, conferindo, ainda, ao suporte fático, o crisma da juridicidade com todos os seus atributos da ordem prática.

Adverte CRISCUOLI que o ordenamento jurídico reconhece a plena liberdade negocial, podendo o particular regular os seus próprios interesses da melhor maneira possível, mas se um sujeito decide regular através de um preceito os seus interesses é preciso que seja conforme a ordem jurídica, de acordo com os preceitos de direito objetivo, pois não se pode dizer que a relação de uma fattispecie contra jus possa permanecer indiferente ao direito e que não importa uma reaçāo sua.

A nulidade, já salientamos, consiste numa sanção, é um ônus, o qual deve ser observado, pois quando não se respeita os limites legais, importando em uma transgressão, a sanção será a nulidade do ato ou negócio jurídico.

Em caso de transgressão será imposta a sanção da nulidade. Assim, quando o ato ou negócio, em sua parte de suporte fático, não está conforme ao ordenamento, existe uma sanção de ordenamento civil, imposta pela lei, que é a de declarar parcialmente nulo o ato ou negócio. 
Diz CRISCUOLI: "A nulidade é a forma mais grave de invalidade enquanto uma reação que corresponde a uma posição de inidoneidade absoluta de todo ou parte do negócio, ao passo que a anulabilidade, é uma forma de invalidade, menos grave, como sanção em razão do defeito do negócio no todo ou em parte",(16).

No mesmo passo, como salienta STOLFI: "A nulidade e a anulabilidade do negócio constituem sançōes objetivas, no sentido de que o único pressuposto de sua admissibilidade está na violação da lei, sem que se possam fazer valer em contrário consideraçōes de índole subjetiva" (17).

Do mesmo modo que a nulidade total é considerada como sanção, a parcial apresenta as mesmas características. A parte negocial nula não produz efeitos, não pode ser convalidade e, como também, sua ação não é passível de prescrição, como princípios gerais.

BETTI ao cuidar da nulidade parcial, ou melhor, da invalidade parcial, uma vez que o negócio pode ser nulo e anulável parcialmente, explica que "quando o negócio esteja viciado apenas numa parte do seu conteúdo preceptivo, entendido o vocábulo "parte" como referido ao âmbito daquele conteúdo ou apenas quanto a uma das diversas disposiçōes de que consta, é abstratamente possível tanto a solução segundo a qual a invalidade se mantém, precisamente, parcial, isto é, circunscrita àqulea disposição ou àquela porção do conteúdo preceptivo do negócio (utile per inutile nen vitiatar), como a solução contrária, no sentido de que o vício da parte se comunica ao resto", submetendo ao regime de invalidade total do negócio, quando a parte sã é afetada (18).

O direito italiano adota como princípio a primeira orientação, no sentido de que só parte viciada é que se mantém nula, ou melhor, inválida. Já, no direito alemāo, sucede justamente o contrário, quando a parte sã se torna afetada, invalidando todo o negócio, ao adotar o critério da invalidade total.

\subsection{A NULIDADE PARCIAL NAS DIVERSAS ESPÉCIES DE NEGÓCIOS:}

\subsubsection{Negócios típicos e atípicos.}

Segundo CRISCUOLI não existem diferenças entre o tratamento a ser dado nessas duas espécies de negócios. Típico ou atípico, e negócio se insere na regra geral do art. 1419 do código Civil italiano, in verbis:

(16) CRISCUOLI, op. cit., p. 136.

(17) GIUSEPPE STOLFI. Teoria del Negocio Jurídico, p. II ().

(18) BETTI, op. cit., tomo III, p. 42. 
"A nulidade parcial de um contrato ou a nulidade de cláusulas singulares, importa em nulidade do contrato inteiro se resultar que os contraentes não o teriam concluído sem aquela parte de seu conteúdo que foi ferida de nulidade".

Por sua vez, "nulidade das cláusulas singulares não importa em nulidade do contrato quando as cláusulas nulas forem substituídas, de pleno direito, por normas imperativas."

\subsubsection{Negócios simples e complexos.}

Na conceituação dada por BETTI, negócios simples são aqueles que consistem num único ato (declaração ou comportamento). Já, os negócios complexos, são aqueles que resultam da fusão orgânica e incindível de diversos atos, sem eficácia cada um de persi.

Conforme sua classificação, o negócio complexo apresenta dois aspectos: objetivo e subjetivo.

A complexidade será objetiva, quando o negócio conste de várias declarações destinadas a regular a mesma matéria, as quais, pelo menor implicitamente, se referem umas às outras; e em todos as declarações de que consta, ele é obra do mesmo sujeito. Por exemplo: "Pense-se numa disposição testamentária, ou numa proposta contratual, que constem de uma pluraridade de cláusulas, talvez cronologicamente distantes umas das outras (testamento e codicilo; proposta inicial e fatura; cláusula compromissória acrescentada ao texto convencionado do contrato), onde considera-se essencial a esta forma de complexidade, a identidade, tanto do sujeito como do objeto do negócio."

Por outro lado, a complexidade será subjetiva, "quando consta de declarações ou comportamentos homogêneos, concernentes ao mesmo objeto, e que são obra de dois ou mais sujeitos diferentes".

Esclarece BETTI: "Sempre que num negócio participem vários sujeitos, só por isso ele é constituído, também, por uma multiplicidade de declaraçōes ou comportamentos reciprocamente complementares, e, por conseguinte, é um negócio complexo, e quando aqueles são cronologicamente distintos entre si, configura, logo, uma fattispécie de formação sucessiva ${ }^{(19)}$.

O negócio de formação sucessiva é aquele consistente em vários atos sucessivos, que se qualifica em sentido ampio de processo, com vários atos jurídicos sucessivos, dirigidos à mesma finalidade, dos quais cada ato que se segue

(19) BELYT, op. cit., tomo II, p. 190. 
pressupōe, necessariamente, o procedente, e prepara e preanuncia o subseqüente. Ex. a relação entre a autorização e o autorizado, no qual existe uma ligação entre a autorização da autoridade e o negócio autorizado.

CRISCUOLI como exemplo de negócio objetivamente complexo, do mesmo modo que BETTI, dá o exemplo do testamento, no qual consta uma pluralidade de disposições ou convençóes dirigidas a regular uma mesma matéria, com uma mesma causa objetiva, ou um contrato de compra e venda no qual se acresce uma cláusula penal.

Para CRISCUOLI, o negócio subjetivamente complexo é denominado pluripessoal; (objetivamente complexo) quando formado de várias pessoas, seja unilateral ou plurilateral; será unipessoal, quando a manifestação de vontade promana de uma única pessoa.

E adverte que a complexidade subjetiva e objetiva podem concorrer num mesmo negócio.

Quando a nulidade parcial no negócio subjetivamente complexo (quando consta de declaraçōes ou comportamentos homogêneos, concernentes ao mesmo objeto, por obra de dois ou mais sujeitos diferentes), assim se apresenta: "O negócio consta de uma ou mais partes, em que a participação de uma delas se apresenta nula". Neste caso, dá-se a invalidade, que ocorre quando na sua constituição, um dos seus elementos não tenha os requisitos, ou, as qualidades exigidas pela lei.

\subsubsection{Negócios jurídicos unilaterais: inter vivos e mortis causa.}

$\mathrm{Na}$ definição de EMILIO BETTI, o negócio unilateral é aquele realizado apenas por uma parte, em virtude de uma única ou idêntica legitimação para o negócio, os quais se dividem em:

a) negócios subjetivamente simples: É aquele com um único autor. Um negócio desta espécie só pode ser unilateral, quando, não obstante a declaração deva dirigir-se a um determinado destinatário, este não se torna parte do negócio, não sendo chamado a concorrer para ele com o seu consenso ${ }^{(20)}$

b) negócio subjetivamente complexos: Assim se considera, "quando a participação de várias pessoas num mesmo negócio se dá em virtude de uma comum e igual legitimação, para a tutela de um mesmo interesse, e portanto, de maneira que elas estejam todas do mesmo lado. É o que se dá nos atos colegiais em sentido lato; isto é, nos atos e negócios realizados por diversas pessoas,

(20) BETTI, op. cit., tomo II, p. 194. 
como: a) componentes do mesmo organismo, ou b) contemporâneamente investidas da representação de uma mesma pessoa, ou d) por qualquer outro modo cooperantes para a realização do interesse desta", nas palavras de BETTI ${ }^{(21)}$.

Os negócios entre vivos, por sua vez, não são "aqueles cuja função econômico-social corresponde à prática da vida nas suas diversas exigências e destinados a desenvolver-se nela sem ter em conta a morte de seus autores".

Já, os negocios mortis causa, segundo EMILIO BETTI, são aqueles em que "a morte é prevista, não arbitrariamente, como qualquer outro evento, estranho à estrutura do negócio, mas necessariamente, como elemento característico da própria causa do negócio. Em relação ao negócio, e evento da morte funciona como elemento característico da própria causa, como condicie iuris, e é juntamente com o negócio, um elemento constitutivo daquele fattispécie complexa que tem por efeito a aquisição ou a sucessão mortis causa, visto que o negócio, só por si, não produz ainda, enquanto não sobrevier aquele evento, nenhum dos efeitos jurídicos que a lei liga ao seu tipo"' (22).

"Observadas as disposições da lei em contrário, as normas que regulam os contratos são aplicáveis, desde que compatíveis aos atos 'inter vivos' unilaterais que têm conteúdo patrimonial".

Duas observaçōes devem ser postas: A primeira, é a de que o Código italiano não apresenta uma norma de caráter geral que regule os atos unilaterais, pois trata apenas das normas que são compatíveis com os atos 'inter vivos' de conteúdo patrimonial; em segundo a referência à incompatibilidade é vaga e imprecisa.

Por outro lado, quanto aos atos unilaterais causa mortis, não existe no diploma italiano uma norma aplicável, tal qual para os atos "inter vivos". No caso do testamento, que é a figura típica, representativa dos atos "mortis causa", e seu tratamento é dado à parte, de acordo com o instituto.

O fato é que o testamento contém uma pluridade de disposições absolutamente independentes e por sua natureza faz com que a vontade do testador seja respeitada o mais possível, procurando-se a conservação do testamento parcialmente nulo. Dada a especialidade do negócio, no testamento, aplica-se o princípio da prevalência da vontade do testador.

Como assinala CRISCUOLI: “... la partìcolare incapacità a testare dell'infermo dimente, anche se nos interdetto, per esempio; la revoca della disposizio-

(21) idem, ibidem, p. 194

(22) BE:TTI, op. cit. tomo II, p. 210. 
ne per alienazione della coza legata; la possibilità di impugnativa per semplice errore sul motivo; il divieto del testamento per rappresentanza e del testamento cumulativo e reciproce; nonchè tutta la serie di prescrizioni formali imposte dalla legge a garanzia della certeza della volontà del siponente, dimonstrano chiaramente quanta importanza abbia questa nel negozio testamentario".

E acrescenta: "Per quanto riguarda, pei, il principiodell' economia giuridica, la conservazione del testamento parzialmente nullo treva maggiore giustificazione nella considerazione della impossibilità della rinnevazione dell'atto da parte del testatore ${ }^{(23)}$.

O testamento parcialmente nulo, de fato, em razão da importância do instituto, na qual a vontade do testador deve ser tutelada, faz com que, diante do princípio de economia jurídica, deva ser conservado, em virtude da impossibilidade de renovação do ato pelo testador.

Afirma BETTI que o testamento "é um ato que pode conter diversas disposições, cada uma das quais tem, por si, valer de negócio: instituição de herdeiro, legado, partilha de ascendente, nomeação de executor testamentário, reconhecimento de filho natural. Portanto, mais do que como um negócio, o testamento apresenta-se como uma forma apta para recolher uma pluridade de negócios, tendo a morte por causa" (24).

Portanto, o regime da nulidade parcial adotado para os negócios inter vivos, vale para os negócios mortis causa, mas com a especialidade de que, o testamento, por princípio de economia jurídica, e em razão da natureza e da estrutura do ato, deve-se resguardar o mais possível a vontade do testador, em face de sua maior significação, como foi visto por CRISCUOLI.

No testamento, como ato unilateral, não há necessidade do conhecimento de terceiro para que seja perfeito, pois, não se constitui entre o de cujus e o destinatário da declaração; mas se se constituisse entre terceira pessoa, esta não estaria obrigada a um determinado comportamento diante do testador; não surgindo, ainda, nenhuma necessidade de se tutelar a boa fé, como assevera CRISCUOLI; o que o torna um ato especialíssimo.

EMILIO BETTI, do mesmo modo, exige para o testamento um tratamento liverso, não só pela unilateralidade, como pela causa.

(23) CRISCUOLI, op. cit., p. 149.

(24) BETTI, op. cit., p. 211. 


\subsection{4. negócios patrimoniais e não patrimoniais.}

Segundo o conteúdo dos negócios jurídicos, estes se classificam em: patrimoniais e não patrimoniais.

O conteúdo preceptivo do negócio é o novo arranjo que as partes dão aos seus interesses, nas relaçōes entre elas: esse conteúdo varia, portanto, conforme a natureza dos interesses em jogo e das relaçōes que se têm em vista com o negócio ${ }^{(25)}$.

Os negócios patrimoniais, como ensina BETTI, em geral, destinam-se a "modificar a existente distribuição dos bens, ou a assegurar formas de cooperação (serviços) entre associados, com vista ao interesse recíproco ou ao interesse de uma só parte, e aos vários tipos de escopos práticos das partes corresponde a constituição, a extinção ou a modificação das relações jurídicas patrimoniais. $\mathrm{O}$ conteúdo de tais negócios é, portanto, na consciência das partes, uma atribuiçāo patrimonial, em sentido lato: ou seja, nas relações entre os interessados, uma mudança patrimonial, social e juridicamente relevante".

BETTI distingue ainda, os chamados negócios de segundo grau, que não se confundem com os negócios de atribuição patrimonial, como é o caso do reconhecimento, da transação, do compromisso e da arbitragem. Estes negócios visam "a um arranjo de interesses com base na situação existente (statu que), por conseguinte ao acertamento das relações preexistentes e reflexamente uma atribuição patrimonial, que pode resultar, é de modo indireto e não necessariamente intencional.

Quanto aos negócios de atribuição patrimonial, estes se dividem em duas espécies: negócios de disposiçāo e negócio de obrigação.

Os negócios de disposiçāo são aqueles que importam uma diminuição jurídica do patrimônio, isto é, importam a perda, limitação ou destinação mortis causa de direitos patrimoniais. A Disposição pode ser translativa (constitutiva) ou meramente abdicativa: alienação (cessao) ou renúncia.

Os negócios de obrigaçāo, por sua vez são aqueles que se contrapõem aos de disposição, dado que o regulamento de interesse que eles realizam não é, pelo menos imediatamente, uma modificação da posição dos sujeitos em relação aos bens, e portanto uma nova distribuição destes, mas sim uma forma de cooperaçāo entre consociados, coordenada com os interesses recíprocos ou com o interesse unilateral de um deles. Todavia, os negócios de obrigação não pro- 
duzem uma diminuição atual e imediata do patrimonio (quem assume uma obrigação não se despeja, na altura, de nenhum direito): e isso distingue-os dos atos de disposição que, ao invés, determinam uma diminuição imediata, ou pelo menos, ficam na dependência do evento morte ${ }^{(26)}$.

O Código Civil italiano, nos arts. 1419 e 1324 que tratam dos casos de nulidade parcial e dos atos unilaterais, como já tivemos oportunidade de demonstrar, referem-se aos atos ou negócios de conteúdo patrimonial, com as ressalvas dadas ao testamento, o qual, diante do princípio da economia jurídica, enquadra-se nos parâmetros da conservação.

\subsubsection{Os negócios familiares.}

Os negócios familiares são os que regulam interesses de família. "São os atos onde a autonomia individual está vinculada a uma instância superior, que transcede o indivíduo como tal: o interesse de núcleo familiar" (27).

Como EMILIO BETTI, CRISCUOLI os designa com atos do poder familiar, isto é, que têm causa por causa o interesse familiar. Nesses atos, o que se procura, em virtude do interesse que resguarda, é a conservação, dentro do princípio utile per inutile non vitiatur, do ato inválido.

Pois, como assinala CRISCUOLI, o regime da nulidade parcial dos atos familiares é particularmente diverso dos negócios patrimoniais: a nulidade parcial do ato, que vai de encontro a conservação coativa da sua parte válida, resulta do critério da imediatividade devido a exigência superior advinda do direito de família. Nestes está em jogo o interesse familiar, que é o interesse do Estado mesmo ${ }^{(28)}$.

Por exemplo, nos casos em que se apõe uma cláusula condicional ou um termo, nos atos matrimoniais, estas serão consideradas como não escritas, permanecendo válido o casamento. Do mesmo modo, o reconhecimento de filho, ao qual nāo se pode apor termo ou condição, uma vez que ao genitor nāo é dado estabelecer eventual limitação e eficácia ao ato. Nestes aspectos, a vontade individual é limitada, em razão de que o comportamento do sujeito deve se circunscrever às normas legais, impostas e coativas, na limitação da liberdade individual, sob pena de nulidade da cláusula limitativa contrária.

Portanto, estas disposiçōes limitativas, nulas, ter-se-ão como não escritas, conservando todo o ato como válido, dentro do princípio da conservaçāo.

(26) Idem, ibidem, p. 168/178.

(27) BETTI, op. cit., tomo II, p. 168

(28) CRISCUOLI, op. cit., p. $150 / 159$ 


\section{3. - O princípio da conservaçäo:}

Quando o legislador procura conservar a parte não eivada de invalidade de um negócio; quando ocorre a nulidade parcial do ato ou negócio, funda-se no chamado princípio de conservação.

Este princípio faz com que se mantenha a salvo, resguardando o mais possível, os valores criados no mundo jurídico.

A norma do art. 1419.do Código Civil italiano; trata do princípio da conservação dos negócios jurídicos. Com isso, existe a conveniência, baseada no fundamento da economia jurídica, de se manter em vida o negócio parcialmente nulo, na sua parte sã, legitimado o princípuio da conservação.

Mas, para que ocorra a prevalência de se manter conservada a parte do negócio, em que é válida, vários pressupostos devem ser observados, pois a aplicação desse princípio não pode ser feita pura e simplesmente.

Funda-se, este princípio, em outros dois princípios, a saber: o da autonomia privada e o da economia jurídica.

O Cânone da autonomia privada em confronto com a nulidade parcial, segundo CRISCUOLI, pode resumir-se na seguinte fórmula: "O ordenamento jurídico não pode 'invalidare e rendere nulo' quando seja produto direto da autonomia privada, pois isso, em linhas gerais, dá 'reiconoscimento, ove non esistano ragioni per cui siffato prodotto non possa essere riconosciuto come tale, ma come frutto di essa deve necessariamente tendere"(29).

A autonomia privada é reconhecida pela doutrina como a faculdade ou o poder atribuído pela lei para a regulamentação particular e concreta de um interesse. É o poder de se criar preceitos vinculantes em conformidade com os princípios fixados pelo direito objetivo. O preceito legal é o pressuposto de seu reconhecimento jurídico.

Disto, resulta que: ou se reconhece que o ordenamento jurídico deve reconhecer válido tudo quanto resulta criado com base na autonomia de vontade; ou, se deverá admitir que a lei sancione de nulidade o que seja criado em conformidade com os seus princípios e sobre um poder atribuído por ela mesma.

Observa CRISCUOLI que a autonomia privada, diante de sua própria etmologia, apresenta um duplo sentido: de um modo amplo e geral, como a facul- 
dade de regular os proprios interesses de maneira mais livre possível; e num sentido mais restrito e particular, como poder de dar um regulamento aos próprios interesses em conformidade aos preceitos assinalados pelo "ordiamento jurídico."(30).

Destas duas fórmulas, a primeira deve ser totalmente descartada, uma vez que não corresponde "à realidade e em particular, nāo respeita a função do indivíduo na sociedade".

Dentro da melhor doutrina, a autonomia privada é reconhecida como um poder diretamente derivado do ordenamento jurídico. "Il rilievo scaturisce, anzitutto, dall essenza stessa dell'autonomia, non pressupponendo essa "nè um originario potere statutario, nè una autorizzazione all'autoregolamento dei rapporti, come nel campo del diritto ammnistrativo per gli enti local"(31).

Mui acertadamente CRISCUOLI diz que "agir com base na autonomia privada é um agir secundum ius, enquanto se está afeto ao exercício de um poder legitimamente atribuido".

Quando criada uma fattispécie negocial, esta pode estar perfeitamente conforme os limites assinalados pelo direito. Neste caso, tratando-se de preceito secundum ius, ele será vinculante entre as partes, reconhecido pela ordem jurídica.

Ora, quando ocorre a nulidade parcial, quer dizer que uma parte do negócio está conforme o ordenamento jurídico, válida, reconhecida, como verdadeiro regulamento de interesses. Seria sem razão considerar inválida a parte váli$\mathrm{da}$, constituindo uma grave injustiça, como diz CRISCUOLI, "una palese contraddizione porre, da un canto, dei limiti all'autonomia privata e riconoscere, dall'altro, come possibile il loro superamento ed inoltre atribuide alle parti il potere di creare negozi giuridici nell'ambito della legge e riconoscere, poi, come giuridico quanto creato in forza di uno sviamento di questo potere".

A conclusão é que a garantia parcial do negócio jurídico se harmoniza com o princípio da autonomia privada.

Resulta que a conservaçāo do negócio jurídico parcialmente, quando nāo resulta essencial a sua parte inválida, repousa sobre uma presunção de ordem lógica e prática, em conformidade ao princípio da economia jurídica.

(30) CRISCUOLI, op. cit., pág. I07.

(31) Idem, ibidem, pág. 109. 
Pois, a regra - utile per inutile non vitiatur - devida aos glosadores, teve as suas origens desde o direito romano, em que a nulidade parcial de um negócio não importava a nulidade total, quando a parte nula do negocio nao fosse a principal, mas simplesmente acessória em relação à parte válida, de modo que, considerando inválida a parte insanável, o negócio podia perfeitamente produzir os seus efeitos.

Os romanos, inicialmente, não conheceram um conceito abstrato de nulidade parcial. As suas origens, na realidade, foram compilatórias. Mas, alguns autores, como CRISCUOLI, admitem que os clássicos conheceram, de certa forma, a nulidade parcial. Tanto que, em casos de testamento, em muitas hipóteses se admitiu a nulidade testamentária parcial. Na verdade, não havia um conceito abstrato de nulidade parcial, pois, somente com Justiniano, é que se conheceu o instituto.

E assim, a regra utile per inutile non viatiatur foi firmada pelos glosadores, dadas as interpolações dos textos, quando a nulidade parcial passou a ser reconhecida. O fato é que os romanos, tanto no direito clássico, como pós-clássico, não conheceram a nulidade parcial como instituto. Só mais tarde, com o grande relevo dado aos negócios e à manifestação de vontade, diante da própria complexidade dos mesmos, é que foi possível tratar da cisão do negócio, principalmente quando este apresentava diversos objetos e conteúdos.

\section{4. - A nulidade parcial em nosso ordenamento:}

(51). PONTES DE MIRANDA ao tratar da nulidade total e parcial, inicialmente, fala daquilo que a nulidade atinge. Para o jurista, é o ato jurídico que é nulo. Nunca os efeitos. "Quando se diz 'crédito nulo', 'obrigação nula', em verdade se usa de elpse: crédito oriundo de ato jurídico nulo (ou de parte nula do ato jurídico)", obrigação oriunda de ato jurídico nulo (ou de parte nula de ato jurídico). Crédito e obrigação, são efeitos; efeitos são ou não são, existem ou não existem; efeitos não são válidos ou inválidos. $O$ que é nulo é o negócio jurídico.

PONTES DE MIRANDA assevera que nāo se pode pensar em nulidade parcial, sem se pensar em negócio jurídico complexo. Todas as causas de nulidade são possíveis causas de nulidade parcial. "Se a parte nula é essencial a todo o negócio jurídico, nulo é todo ele. Nāo há contrato, se é nula a oferta, ou se é nula a aceitação. A inseparabilidade resulta da natureza do negócio ou do ato jurídico stricto sensu, ou da subordinação do todo à parte nula, no caso de saberem os que manifestaram a vontade, ou de o saber o que a manifestou, que seria nula a parte. Isto é: qual teria sido a conduta deles, ou dele, quanto ao resto. Certo, quem quis o ato jurídico o quis todo, mas as circunstâncias podem mostrar que se quis o resto, ainda sem a parte. Assim se chega à discriminação 
do suporte fático em minímo que seria de admitir-se (desejar-se) e máximo que seria atingível pela nulidade sem que se excluisse o resto"(32).

O princípio de nosso ordenamento está consignado no art. 153, nestes termos: "A nulidade parcial de um ato não o prejudicará na parte válida, se esta for separável. A nulidade da obrigação principal implica a das obrigações acessórias, mas a destas não induz a da obrigação principal".

Para PONTES DE MIRANDAZ, este princípio resulta da "unidade do ato jurídico, a despeito da sua complexidade; as exceções emanam dessa complexidade, quando se afrouxa o laço interno a ponto de se terem por separáveis as partes dele. Por isso mesmo, se há pluralidade de atos jurídicos, o princípio primeiro é o princípio da não-contagiaçāo e só excepcionalmente da dependência íntima entre eles, ou parte deles, permite que se abra brecha ao princípio, em que uma das pessoas figurantes é menor de dezesseis anos, e por ele foi vendida casa em que cada pessoa tinha parte indivisa, primeiro se há entender que é nulo todo ele, e nāo só parte do menor, cabendo ao adquirente alegar e provar a validade do negócio jurídico no tocante às partes não alienadas pelo menor. A solução do direito comum - lógica, no sistema que ele adotara - seria a nulidade só da parte do negócio jurídico concernente ao menor, salvo aos interessados a alegação e prova da contagiação"(33)

No direito alemão a regra é inversa; Dispõe o $\$ 139$ do BGB: "Se uma parte de um negócio jurídico for nula, será todo o negócio jurídico senão deve ser admitido que, mesmo sem a parte nula, havia de ser ele realizado".

Ensina VON THUR que para "aplicar-se esta disposição, o juiz deve colocar-se no lugar das partes e perguntar-se que haveriam estabelecido elas em caso de saber que a cláusula proibitiva carecia de eficácia. Não se trata de interpretar a sua vontade, pois, na realidade, (inclusive o elemento nulo) os contratantes quiseram todo o negócio, inclusive o elemento nulo, a não ser na hipótese que incumbe ao juiz estabelecer, e que tem por objeto imaginar como se haveria configurado a vontade das partes em caso de apresentar certas circunstâncias. O ponto de partida, como diz VON THUR, é que as partes medem e regulamentam razoavelmente os seus interesses. Do que se depreende que o elemento do negócio que não está afetado pela nulidade é válido quando, segundo o ponto de vista da parte - ou das partes, em caso de negócio plurilateral -, constitue o principal ou, ao menos, o mínimo desejável com relação a todo o negócio assim como estava projetado",(34).

(32) PONTES DE MIRANDA - Tratado - vol. IV - pág. 51/2.

(33) PONTES DE MIRANDA - Tratado - pág. 52 - tomo IV

(34) ANDREAS VON THUR - Derecho Civil - vol. III/l . pág. 314/5. 
Observa-se aqui, que PONTES DE MIRANDA adota os princípios formulados por ANDREAS VON THUR, ao determinar a aplicação de que é nulo todo negócio, mandando, ainda, que as partes devem manifestar-se quanto à parte desejável.

O nosso sistema difere do sistema alemão. Entre nós, a regra geral é que a nulidade total deve ser provada. $\mathrm{E}$ o ônus da prova incumbe a quem assume a nulidade total.

Do mesmo modo, na doutrina italiana, como diz STOLF: "A regra só não é aplicável, quando resulta que os contratantes não teriam realizado o ato sem aquela parte de seu conteúdo que é inválida. Isto significa que entre as duas partes do ato pode estabelecer-se uma relação de principal e acessória e distinguir conforme a nulidade afete a principal ou a secundária; na primeira hipótese a nulidade parcial equivale à total, e, por conseguinte, a ineficácia da disposição principal se estende as que dela dependem; na segunda hipótese a nulidade parcial afeta unicamente a disposição acessória e deixa intacta a principal"(35).

Em conclusão, podemos afirmar que em razão da invalidade de uma parte do negócio jurídico, esta restará inválida. No caso da nulidade, segue os mesmos pressupostos da mesma, em sua extensão.

A parte declarada nula, como inválida que é, não entrará no plano de eficácia, pois a porção nula do conteúdo preceptivo do negócio é destituída de validade. Muitos autores, entre eles, CRISCUOLI, diz que "é destituída de nenhum efeito jurídico".

Com base nos três planos distintos em que atua o negócio jurídico, na lição de ANTONIO JUNQUEIRA DE AZEVEDO consideramos inválida a parte que não apresenta os requisitos, as qualidades exigidas pela lei para permanecer no mundo jurídico. Quer dizer que, os elementos contidos naquela parte, sejam gerais, sejam categorias ou particulares, restarão destituídos de qualidades.

$\mathrm{Na}$ introdução do presente estudo, mostramos que muitas vezes, a invalidade do negócio, muitas vezes, se subsume na inexistência, em razão da proximidade dos dois planos, e do seu paralelismo, em razão da proximidade dos dois planos, e do seus paralelismo. Então, não podemos dizer que a parte nula é destituída de efeitos, mas, inválida, isto é, destituída de qualidades que a fazem estar de acordo com as regras jurídicas. Pois, muitas vezes, pode ocorrer que a parte nula, apresente-se eficaz, o que ocorre nos casos em que advenha um fator de eficácia. 
Por outro lado, pode acontecer que a parte dita válida, seja ineficaz, por falta de um fator de eficácia.

É o que veremos, com maior cuidado, a seguir, quando tratarmos das conseqüências da nulidade parcial.

\section{5. - A nulidade parcial - características:-}

Para que ocorra a nulidade parcial é preciso que haja separalidade das partes. Como diz PONTES DE MIRANDA: "tem o juiz de verificar se o objeto do ato jurídico permitirá que se separassem as partes dele, correspondentes aos diferentes figurantes. Somente após a resposta quanto à possibilidade da separação, é que se há de inquirir do que quiseram as pessoas, e se teriam querido o mesmo, se soubessem que a parte ou partes do ato jurídico seriam tidas por nulas. Naturalmente, já se não cogita da pessoa ou das pessoas que derem causa à nulidade. A mesma atitude se deve assumir em face das outras nulidades: se proveio de infração de regra jurídica sobre forma, ou se ilícito ou impossível o objeto, ou se foi preterida alguma solenidade, que a lei considere essencial à validade, ou se há regra jurídica especial sobre a nulidade (art. 145, II-V)"(36).

A nulidade parcial, como assevera CRISCUOLI, é uma sanção que corresponde a um estado de nāo ser jurídico (stato di non essese giurídico) da parte negocial inválida.

Sabemos que uma das características essenciais da nulidade é a sua insanabilidade. Mas, vimos que muitas vezes, por exceção a essa regra geral, é possível a sua sanabilidade. Vimos, também, que o nulo pode produzir efeitos, o que faz com que na nulidade parcial, na obsta a que estas exceções surjam, de modo que todo o ato possa ser considerado válido, para efeitos de penetrar no mundo da eficácia.

Conforme as palavras de CRISCUOLI: "Se il dichiarante o i contraenti hanno intezione di ditenere gli effeti della parte negoziale nulla, unitamente a quelli della parte valida, devono o ripetere il negozio, eliminando (a queli della parte la causa della nulità parziale, ovvero accetare, intanto, gli effeti del negozio per la parte valida e contemporaneamente creare ex novo un altro negozio avente lo stesso oggetto della pattuizione nulla, ma purificato dalla sua causa di nulità, collegandolo al precedente per i rlaggiugimento dell'effeto generale originariamente disato"(37).

Outra particularidade, é aquela apontada por PONTES DE MIRANDA, de que o art. 153 não incide sobre os atos de disposição: pois, precisa-se rein-

(36) PONTES DE MIRANDA - Tratado - vol. IV, pág. 53

(37) CRISCUOLI - op. cit., pág. 261. 
vidicar a coisa, pois a disposição tem de ser desfeita pela restituição. "A sentença por exemplo, quanto à nulidade do contrato de compra e venda somente descontitui esse contrato: não vai á disposição, que foi cumprimento. Razão por que se há de pedir a restituição. $O$ juiz que determinasse a volta da coisa entregue, julgaria ulrta petita: em açāo constitutiva, negativa, executoria".

Outra característica é a de que, em se tratando de ato parcialmente nulo, o juiz pode decretar de ofício, "para além do alegado; ou se julgar provada a nulidade da parte separável. A exigência da alegação só concerne à anulabilidade; quanto à nulidade, somente a regra jurídica especial pode excluir a decretação de ofício. Donde se conclui que a diferença é a priori e se prende aos dois conceitos de nulidade e anulabilidade. No mesmo negócio jurídico, é de ocorrer que uma parte seja nula, e outra, anulável. Então, se separáveis, cada uma se rege por seus princípios próprios. Se há três partes e uma delas nem é nula, nem anulável, a separabilidade permite que a terceira fique a coberto pela regra "Utile per inutile vitiatur" (38).

Postas essas características primordiais, passaremos às conclusões de nosso estudo, adiantando desde já, que em razão da profundidade do tema e dos inúmeros problemas que envolve, não nos foi possível tecer maiores considerações a respeito da várias espécies de aplicabilidade da nulidade parcial.

\section{6. - Conclusōes:-}

Em nossas noções introdutórias mostramos os três planos apresentados por ANTONIO JUNQUEIRA DE AZEVEDO, nos "quais a mente humana deve sucessivamente examinar o negócio jurídico, a fim de verificar se ele obtêm a plena realização".

Vimos que para que um negócio seja válido, precisa existir, e que quando inválido, permanece apenas no plano da existência, uma vez que não se pode confundir os dois planos em que se projeta o negócio. Isto tem a sua razão de ser, pois a maioria dos doutrinadores confundem a invalidade do negócio com a sua ineficácia, o que não pode ser aceito.

No plano da validade, o que se busca são as qualidades de que se reveste o negócio, qualidades essas consideradas requisitos, que são os caracteres exigidos pela lei, para a sua conformidade legal. Diante do princípio da autonomia da vontade, em que os efeitos do negócio devem ser aqueles que estão na dependência dos efeitos manifestados como queridos, os que os diferencia como uma espécie de fatos jurídicos, lei impõe limites a essa autonomia, ao conteúdo 
preceptivo do negócio que deve respeitar os requisitos requeridos pelo ordenamento.

Isto tem a sua importância, pois quando se dá a nulidade parcial, ou melhor, a invalidade parcial, o que se tem em vista, é não-regularidade do ato ou negócio, a falta de qualidades após aos elementos, sejam eles, gerais, constutivos ou particulares, que se configuram no plano da existência. Assim, não se pode considerar a nulidade como a falta de produção de efeitos do ato, mas, sim, como falta de regularidade que faz com que seja insusceptível de entrar no plano da eficácia, e completar a sua realização.

Outra característica apontada é a de que, um ato pode ser considerado inválido, mas mesmo assim, produzir os efeitos, e isto, se aplica ao nosso tema, a nulidade parcial, pois um ato parcialmente inválido, pode, por sua vez, ser eficaz.

A nulidade, diante das palavras de BETTI e de CRISCUOLI é considerada a sanção mais grave imposta pela lei, e com ela, o ato torna-se impossível de convalidação.

Em JAPIOT, o critério da distinção é o interesse público ou privado, abolindo a dicotomia entre atos nulos e anuláveis, levando em consideração que a invalidade corresponde a uma sanção. Desse modo, a invalidade se fundamenta no direto de crítica dirigido contra o ato, cujo escopo é prático, no sentido de suprir o fato objetivo que é a consequêencia do ato. Assim, criticando a doutrina clássica, para JAPIOT a invalidade não se considera um estado do ato. Desse modo, não se pode considerar o ato nulo, como aquele desprovido de efeitos, como é correnta na doutrina.

Quanto a classificação das nulidades em absoluta e relativa, LUTZESCO demonstra que "a teoria das nulidades não está estruturada sobre princípio imutáveis; quer se trate de nulidades absolutas ou relativas, em um como em outro caso, só existem lineamentos gerais. Por isso, o legislador estabeleceu a regra, dando a entender que a noçāo de ordem pública está protegida pela nulidade absoluta". Questiona LUTZESCO, se através das disposicões destinadas à proteção de um interesse privado não existem os elementos de ordem pública. Responde o autor, com a sua negativa, mostrando que as renúncias antecipadas a tal proteção seriam a melhor prova para desmentirmos. O fato é que, "enquanto a nulidade absoluta tem por missão assegurar diretamente a salvaguarda do interesse geral, a nulidade relativa tem por fim direito e imediato defender o interesse privado, vale dizer, o interesse protegido (do particular), mas indiretamente também obra em proveito do interesse geral, pois através de seus efeitos sempre é o interesse público o protegido. Ao condenar o dolo e a fraude, 
pergunta, não se trata de realizar o máximo de moralidade nas relações jurídicas de caráter contratual?"

Mas, não deixa de assinalar LUTZESCO os numerosos aspectos da noção de ordem pública. E por outro lado, a nulidade deve modelar-se segundo a natureza das relações sociais que cada dia mudam. Assim, em se tratando da teoria das nulidades, não se pode esperar uma consagração rígida e abstrata de algumas regras inflexíveis face às necessidades sociais. Nada mais falso. Tratando-se de nulidades absolutas ou relativas, "solo habrá, lo repetimos, directrices de ordem más o manos teórico, directrices que deben necessariamente, dar pueba de cierta flexibilidad frente a las dificultades provocadas por las contingencias del medio"(39).

Acrescenta, ainda, LUTZESCO, que "este é todo o segredo da sanção, condenando ou que é contrário à lei, não deve destrir o que não o é. É esta também a razão do aparecimento da nulidade absoluta que carrega a ineficácia total, ou a ineficácia parcial do ato ilícito. Mas, esta flexibilidade não se obterá, pesando, à maneira clássica, os vícios ou enfermidades que tenham afetado o ato jurídico. Não será somente pela apreciação do aspecto de validez do ato de vontade, mas colocando a intenção das partes contratantes frente a frente com o fim social; a nulidade se derivará em certa forma, da natureza do interesse que tenha predominado na opinião do legislador, sem que se possa ignorar o fundo do ato de vontade. Em todo caso, se se quiser conhecer a nulidade que haverá de aplicar-se, é necessário investigar, antes de tudo, se neste conflito a lei tratou de proteger o interesse público ou o interesse privado, em outros termos, a solução será dada pelo fim da lei'"(40).

É de suma importância, para as conclusões e nosso estudo as palavras acima formuladas por LUTZESCO. Pois, em se tratando de nulidade parcial, fim a informar será o interesse público ou privado, levando em consideração, sempre que possível, o velho e antigo brocardo /utile per inutile non vitiatur/ que informa todo o princípio da conservação dos atos e negócios jurídicos, pois estes devem, antes de tudo, procurar ser conservados o mais possível, aproveitando-se ao máximo as partes dos atos que podem ser convalidadas. Além disso, o princípio da economia jurídica, e o pressuposto necessário, o qual fornece o cânone do "utile per inutile", numa base concreta. Pois, "la conservazione del negozio parzialmente nullo, quando non risulti essenziale la sua parte inválida, riposa, quindi, si una presunzione di ordine lógico e prático rigorosissima, conforme perfeittamente al principio della economia giuridica", como afirma CRISCUOLI.

(39) (il:OR(it:S. L utesco. Teoria y Practica de Las Nulidades, p. 242.

(4)) I.UT\%:LS( ) - op. cit. p. 242. 
Assim, chega-se à conclusão de que o que deve informar a nulidade parcial é este princípio, em razão do fato de que a clássica distinção entre nulidades absolutas e relativas, não pode mais prevalecer, em virtude do fato de que, como sanção, o seu caráter é envolvido pelo interesse privado ou público, previamente determinado pelo legislador e que sofrem variações no meio social mudando conforme a época.

Uma vez que em nossos sistemas, tal qual o italiano, o princípio da nulidade parcial é regra, e a total a exceção, faz com que quem a invoca tenha o ônus que ela tem o seu fundamento na particular intenção prática das partes, diferentemente do tratamento dado pelo Código alemão, em que o ônus da prova incumbe a quem invoca a nulidade parcial.

Assim, de acordo com que propõe BETTI, "o tratamento no sentido da invalidade parcial pressupõe, como é evidente, que a cláusula inválida pode cindir-se em duas disposições distintas, susceptíveis uma de se manter e a outra de ser eliminada, ou, respectivamente, que as várias disposições de que consta o negócio, podem ser tratadas como independentes umas das outras, de modo que a invalidade de uma, ou de algumas, possa circunscrever-se a elas e não tenha influência sobre a validade das outras, e seja com elas compatível. Porém, quando a disposição inválida é aquela que seria, de per si, válida, estejam, pelo contrário, conjugadas entre elas por um vínculo de unidade ou de subordinação, a regra "utile per inutile non viatiatur" já não tem fundamento".

Mas, para a aplicação desses princípios todos, necessário se faz que se leve em conta, da melhor maneira possível, o princípio da conservaçāo, tendo como pressuposto e fundamento a idéia de que a clássica classificação das nulidades em absolutas e relativas, já não pode mais permanecer, pois é o interesse público ou privado, que faz que o legislador as leve em conta, como sanção ao preceito da autonomia privada.

\section{BIBLIOGRAFIA}

CORREIA, Ferrara - Erro e Interpretação na Teoria do Negócio Jurídico, 2ః ed., Atlântida, Coimbra, 1968.

ALONSO, Eduardo Serrano - La Confirmacion de Los Negocios Jurídicos, Tecnos, Madrid, 1976.

LARENZ, Karl - Base del Negocio Juridico y Cumplimiento de Los Contratos - Rev. de Derecho Privado, Madrid, 1956, trad. Carlos Fernande $\%$ Rodriguc\%.

LARENZ, Karl - Base del Negocio Juridico y Cumplimiento de Los Contratos - Rev. de Derecho Privado, Madrid, 1956, trad. Carlos Fernande\%. Rodrigue\%.

AZEVEDO, Antônio Junqueira de - Negócio Jurídico - existência, validade e eficácia - Saraiva, S. Paulo, 1974.

VON THUR, Andreas - Derecho Civil - Teoria General - Vol. II, parte 1, Depalma. Buenos Aires, 1947, trad. direta do alemão p/Tito Ravá. 
ENNECCERUS, LUDWIG-NIPPERDEY, HANS CARL - Derecho Civil - Parte General - vol.2, Bosch. Barcelona, 2 $2^{\mathrm{a}}$ ed., 1950 - trad. da 39ª ed. alemã p/Blas Perez Gonzalez e José Alguer.

ALBALADEJO, Manuel - El Negocio Juridico - Bosch. Barcelona, 1958.

GROSSI, Emidio - Nullità del Negozi Giưridici - Genova, Ed. Angelo Lombardo, 1916.

LUTZESCO, Georges - Teoria y Practica de Las Nulidades, Porrúa S/A., México, 1975, trad. de Manuel Romero Sánchez e Julio Lopez de la Cerda.

STOLFI, Giuseppe - Teoria del Negocio Juridico - Ed. Rev. de Derecho Privado, Madrid, 1959, trad. e notas p/Jaime Santos Briz.

CRISCUOLI, Giovanni - La Nullità Parziale del Negocio Giuridico, Giuffrè, Milão, 1959.

FERRI, Luigi - L'Autonomia Privata - Giuffrè, Milão, 1959.

GIORGIANNI, Michele - La Causa del Negozio Giuridico, Giuffrè, Milão, 1974.

IRTI, Natalino - La Ripetizione del Negozio Giuridico, Giuffrè, 1970, Milão.

GARCEZ, Martinho - Nulidades dos Actos Juridicos - vols. 1 e 2, Jacintho Ribeiro dos Santos, Rio de Janeiro, 1910, $2^{\mathrm{a}}$ ed.

MIRANDA, Pontes de - Tratado de Direito Privado - Borsoi, Rio de Janeiro, 1965 - vol. IV.

Idem, ibidem - tomo V.

SOCONAMIGLIO, Renato - Contributo alla Teoria del Negozio Giuridico, 2ª ed., Dott. Eugenio Jovente, 1969. Nápoles.

BEVILAQUA, Clóvis - Teoria Geral do Direito Civil - 2a ed., Francisco Alves, Rev. e atualizada por Caio Mario da Silva Pereira, Rio de Janeiro, 1976.

GUGGENHEIM, Daniel - L'Invalidité des Actes Juridiques - Lib. Générale de Droit et de Jurisprudence, Paris, 1970.

BETTI. Eminio - Teoria Geral do Negócio Jurídico - Vols. 1, II e II, Coimbra, Ed. Coimbra, 1969, trad. de Fernando de Miranda.

GAUDEMET, Eugene - Théorie Générale des Obligations - pub. p/H. Desbois e J. Goudemet-Sirey, Paris, 1965, reimpressão da ed. de 1937.

WINDSCHEID. Bernardo - Diritto delle Pandette - Trad. Fadda e Bensa, Torinense, Turim. 1925. vol. 1.

DERNEBURG. Arigo - Pandette - vol. 1 - parte $1^{\text {: }}$, trad. da $6^{\text {a }}$ ed. alemã p/Francesco Bernardino Ciccala. Fratelli Bocca ed., Turim, 1906.

CARVALHO. Francisco Pedreira de Bulhōes - Ineficácia do Ato Jurídico e a Reforma do Código Civil - Rio de Janciro, 1966. 